\title{
EPIDEMIOLOGICAL PROFILING OF CASES OF 2009 PANDEMIC H1N1 INFLUENZA VIRUS IN A TERTIARY CARE GOVERNMENT HOSPITAL OF CENTRAL INDIA DURING 2015 OUTBREAK
}

\author{
Shiv Shankar Sharma ${ }^{1}$, Sanjay Dubey², Sanjay Dixit ${ }^{3}$, Ashok Thakur $^{4}$, Suraj Sirohi ${ }^{5}$, Satish Saroshe 6
}

${ }^{1}$ Associate Professor, Department of Medicine, M.G.M Medical College, Indore.

${ }^{2}$ Assistant Professor, Department of Medicine, M.G.M Medical College, Indore.

${ }^{3}$ Professor and HOD, Department of Community Medicine, M.G.M Medical College, Indore.

${ }^{4}$ Assistant Professor, Department of Medicine, M.G.M Medical College, Indore.

${ }^{5}$ Assistant Professor, Department of Community Medicine, M.G.M Medical College, Indore.

${ }^{6}$ Assistant Professor, Department of Community Medicine, M.G.M Medical College, Indore.

ABSTRACT: The later part of year 2014 and early 2015 saw a sudden inter-epidemic surge in number of cases of 2009 Pandemic H1N1 Influenza (Swine flu) in India. This study was conducted with intent to see presentation and epidemiological profile of the cases and how it differed from previous years.

METHODOLOGY: This retrospective observational study was conducted by reviewing medical records of all patients with severe Influenza-like illness who required hospitalization between December 2014 and May 2015.

RESULTS: In screening OPD for seasonal flu 11,245 cases were seen from December 2014 till May 2015, out of which 89\% (9245 cases) were of category A and 980 patients were of category B and 397 cases were of category C. All category C cases were advised hospitalization, of which 279 got hospitalized.

DISCUSSION: The incidence in females was more than males and was highest in $15 \mathrm{yr}$. to $45 \mathrm{yr}$. age group. The incidence of severe Influenza-like illness requiring hospitalization in pediatric age group and in age more than 60 was very low. More cases were referred from peripheral hospital of nearby district than getting direct hospitalization.

CONCLUSION: The rural urban distribution in our study was almost equal. The most common presenting complaint in our study was cough followed by fever, shortness of breath, hemoptysis and shock. Sp02 at presentation in our study came out as a promising tool for outcome prediction; this needs further evaluation and may prove to be a simple bedside test for triaging cases with suspected H1N1. In our study we found that lower PaO2/FiO2 values were associated with increase in mortality. The correlation with anemia was most common in our study to the extent that in $100 \%$ female patients with swine flu there was correlation with various grades of anemia (Mild, moderate and severe).

KEYWORDS: 2009 Pandemic H1N1 Influenza, Inter-epidemic Surge, Sp02, Anemia.

HOW TO CITE THIS ARTICLE: Shiv Shankar Sharma, Sanjay Dubey, Sanjay Dixit, Ashok Thakur, Suraj Sirohi, Satish Saroshe. "Epidemiological Profiling of Cases of 2009 Pandemic H1N1 Influenza Virus in a Tertiary Care Government Hospital of Central India During 2015 outbreak." Journal of Evolution of Medical and Dental Sciences 2015; Vol. 4, Issue 93, November 19; Page: 15876-15879, DOI: $10.14260 /$ jemds/2015/2305.

INTRODUCTION: Influenza virus H1N1, (Also known as 2009 pandemic influenza virus or novel influenza virus) was the causative agent of 2009-2010 pandemic of influenza that affected 74 countries. The first case of H1N1 virus was detected in a 10 year old boy of California in April 2009. ${ }^{1}$ At the time of identification, the genetic structure showed no similarities to prevalent human or avian strains, but some similarity was observed with influenza virus of North American swine lineage. ${ }^{1}$ Further studies revealed that H1N1 virus has assorted genetic elements from avian, human and two swine influenza viruses; also it was proven that this virus is circulating in human beings and not pigs, but by then the name 'Swine Flu' has already struck chord with media and masses. ${ }^{1}$

WHO (World Health Organization) declared this virus as a global threat on 25 April $2009 .^{2}$

Financial or Other, Competing Interest: None.

Submission 02-11-2015, Peer Review 03-11-2015,

Acceptance 10-11-2015, Published 18-11-2015.

Corresponding Author:

Dr. Shiv Shankar Sharma,

Department of Medicine,

M. G. M. Medical College,

M. Y. Hospital, Indore,

Madhya Pradesh.

E-mail: drshivssharma@gmail.com

DOI: $10.14260 /$ jemds/2015/2305.
The studies conducted during the ongoing pandemic revealed lower morbidity and mortality rates as compared to other pre-existent influenza virus strains. ${ }^{3}$

On August 10, 2010, the WHO declared an end to the 2009 H1N1 pandemic globally. 4 India being densely populated and temperate climate country too saw its share of H1N1 cases with very high rate of infection during pandemic in 2009, but overall mortality rates were not alarming. From 2010 till later part of 2014, the number of reported patients with suspected H1N1 and influenza-like illness with severe manifestation declined, but the later part of year 2014 and early 2015 saw a sudden inter-epidemic surge in number of cases of 2009 pandemic H1N1 Influenza (Swine flu) affecting thousands of cases all over India with major brunt being faced by few cities of Gujarat, Rajasthan and Madhya Pradesh.

Indore being one of the business centers of Central India saw one of the highest diseases burden in central part of India, where cases referred from more than 20 districts were treated. This study was conducted with intent to see presentation and epidemiological profile of the cases and how it differed from previous years.

We are presenting the epidemiological profile of serious cases with suspected influenza-like illness category C hospitalized at Mahatma Gandhi Memorial Medical College, Indore, from November 2014 till May 2015. 
MATERIAL AND METHODS: This retrospective observational study was conducted by reviewing medical records of all patients with severe Influenza-like illness who required hospitalization between December 2014 and May 2015 at our institute. The screening of patients was done according to MOHFW (Ministry of Health and Family Welfare) and CDC (Centre for Disease Control) guidelines.

All patients presenting with acute onset cough, cold with or without other symptoms like running nose, fever, sore throat and shortness of breath etc., were considered potential cases of H1N1. They were divided into 3 categories according to the severity of symptoms and on the basis of risk factors. Patients with relatively mild illness (Category A and B were managed on outpatient basis while all serious cases who presented with features suggestive of serious risk factors namely shortness of breath, cyanosis, shock and ARDS were hospitalized and managed in isolated intensive care unit.

Patients with mild-to-moderate illness (Category A and B), Patients who died within 6 hours of presentation, and patients who were found to have ARDS secondary to some other cause were excluded from study.

The patients were managed on standard lines with Tablet Oseltamivir, supportive care for shortness of breath and ARDS with invasive/non-invasive ventilator, and other measures. Tab Oseltamivir was given at the dose of $75 \mathrm{mg}$ twice daily.

Throat and nasal swab sample of all patients was taken and sent for investigation in liquid Viral transport media kit. The samples were tested by ELISA for presence of Influenza A and Influenza A H1N1 specific antibodies.

All patients whose reports came positive by RT-PCR (State reference laboratory Jabalpur, Gwalior and All India Institute of Medical Science, Bhopal) for H1N1 were labeled as $\mathrm{H} 1 \mathrm{~N} 1$ positive while the rest were kept as Influenza-like illness category $\mathrm{C}$.

All patients were investigated with complete haematological profile and biochemical profile along with plain $\mathrm{X}$ ray chest PA view. HRCT chest was done if necessary in selected cases depending on need. ABG and oxygen saturation was done on all patients at the time of presentation and repeated as and when required. A 12-lead ECG was taken of every patient and Echocardiography was done as and when required. Depending on the need of individual cases, other investigation were conducted whenever required.
RESULTS: In screening OPD for seasonal flu 11,245 cases were seen from December 2014 till May 2015. Out of which $89 \%$ (9245 cases) were of category A, 980 patients were of category B and 397 cases were of category C. All category C cases were advised hospitalization, of which 279 got hospitalized.

\begin{tabular}{|c|c|c|c|}
\hline $\begin{array}{c}\text { Age } \\
\text { Group }\end{array}$ & $\begin{array}{c}\text { Male } \\
\text { Admitted } \\
\text { (Death) }\end{array}$ & $\begin{array}{c}\text { Female } \\
\text { Admitted } \\
\text { (Death) }\end{array}$ & $\begin{array}{c}\text { Total } \\
\text { Admitted } \\
\text { (Death) }\end{array}$ \\
\hline$<10$ & $5(0)$ & $8(3)$ & $13(3)$ \\
\hline $11-20$ & $12(2)$ & $8(4)$ & $20(6)$ \\
\hline $21-30$ & $13(5)$ & $44(22)$ & $57(27)$ \\
\hline $31-40$ & $23(14)$ & $31(16)$ & $54(30)$ \\
\hline $41-50$ & $34(17)$ & $38(18)$ & $72(35)$ \\
\hline $51-60$ & $19(11)$ & $18(9)$ & $37(20)$ \\
\hline $61-70$ & $11(5)$ & $17(6)$ & $28(11)$ \\
\hline $71-80$ & $3(0)$ & $5(2)$ & $8(2)$ \\
\hline$>80$ & $0(0)$ & $2(2)$ & $2(2)$ \\
\hline Total & 120(55) & $\mathbf{1 7 1 ( 8 2 )}$ & $\mathbf{2 9 1 ( 1 3 7 )}$ \\
\hline Table 1: Showing age and sex distribution of patients with \\
critical H1N1 disease at M. Y. Hospital
\end{tabular}

Total number of hospitalized cases were 291 of which 171 patient's throat swab came positive for H1N1, 108 patients report came negative and in 23 cases test was not performed or sample was rejected due to varied reasons.

\begin{tabular}{|c|c|c|c|}
\hline $\begin{array}{c}\text { Month of } \\
\text { Admission }\end{array}$ & $\begin{array}{c}\text { Male } \\
\text { Admitted } \\
\text { (Death) }\end{array}$ & $\begin{array}{c}\text { Female } \\
\text { Admitted } \\
\text { (Death) }\end{array}$ & $\begin{array}{c}\text { Total } \\
\text { Admitted } \\
\text { (Death) }\end{array}$ \\
\hline January & $4(2)$ & $13(5)$ & $17(7)$ \\
\hline February & $76(36)$ & $102(53)$ & $178(89)$ \\
\hline March & $31(12)$ & $39(22)$ & $70(34)$ \\
\hline April & $5(2)$ & $4(1)$ & $9(3)$ \\
\hline May & $4(2)$ & $3(1)$ & $7(3)$ \\
\hline Total & 120(55) & 191(82) & 291(137) \\
\hline \multicolumn{4}{r|}{ Table 2: Showing Month wise distribution of } \\
patients with critical H1N1 disease at M. Y. Hospital \\
\hline \multicolumn{5}{c}{}
\end{tabular}

A hundred and nine $(76 \%)$ of total cases were females and 560 were males; 56 patients were from urban population and 65 were from rural areas surrounding Indore and nearby district. The distribution of cases around the districts is depicted in this graph. Total number of district from where patient were referred to M.Y. Hospital Indore was 16 and the list includes two districts of Rajasthan.

\begin{tabular}{|c|c|c|c|c|c|c|}
\hline Month & Category A & Category B(I) & Category B(II) & Category C & Hospitalized & Total Patients \\
\hline January 2015 & 1024 & 250 & 123 & 26 & 17 & 1440 \\
\hline February 2015 & 4156 & 561 & 224 & 201 & 188 & 5330 \\
\hline March 2015 & 2654 & 460 & 254 & 78 & 70 & 3516 \\
\hline April 2015 & 680 & 98 & 56 & 13 & 9 & 856 \\
\hline May 2015 & 112 & 19 & 07 & 11 & 7 & 156 \\
\hline Total Patients & $\mathbf{8 6 2 6}$ & $\mathbf{1 3 8 8}$ & $\mathbf{6 6 4}$ & $\mathbf{3 2 9}$ & $\mathbf{2 9 1}$ & $\mathbf{1 1 2 9 8}$ \\
\hline \\
Table 3: Total number of patients of various suspect categories visiting Out-patient \\
Department of cough and cold OPD, Respiratory Medicine and Internal Medicine \\
\hline
\end{tabular}




\begin{tabular}{|c|c|c|c|}
\hline Outcome & Male & Female & Total \\
\hline Death & 55 & 81 & 136 \\
\hline Discharge & 45 & 67 & 112 \\
\hline LAMA & 20 & 22 & 42 \\
\hline Abscond & 0 & 1 & 1 \\
\hline Total & $\mathbf{1 2 0}$ & $\mathbf{1 7 1}$ & $\mathbf{2 9 1}$ \\
\hline \multicolumn{4}{|c|}{ Table 4: Showing Final outcome of } \\
patients admitted to M. Y. Hospital \\
\hline
\end{tabular}

\begin{tabular}{|c|c|c|c|c|}
\hline & Male & Female & $\begin{array}{c}\text { Total No. of } \\
\text { Patients }\end{array}$ & $\begin{array}{c}\text { P } \\
\text { Value }\end{array}$ \\
\hline $\begin{array}{c}\text { H1n1 } \\
\text { positive }\end{array}$ & 69 & 90 & 159 & \\
\hline $\begin{array}{c}\text { H1n1 } \\
\text { negative }\end{array}$ & 46 & 65 & 111 & \\
\hline $\begin{array}{c}\text { H1n1 not } \\
\text { available* }\end{array}$ & 5 & 16 & 21 & \\
\hline
\end{tabular}

Table 5: Showing correlation of throat swab H1N1 positive status and mortality between category $C$ cases

\begin{tabular}{|c|c|c|}
\hline Duration of Illness & Total No. of Patients & $\begin{array}{c}\text { No. of } \\
\text { Patients } \\
\text { Dying }\end{array}$ \\
\hline $0-2$ days & 15 & 6 \\
\hline 3-4 days & 63 & 38 \\
\hline 5-6 days & 78 & 49 \\
\hline 7-8 days & 48 & 23 \\
\hline 9-10 days & 16 & 8 \\
\hline$>10$ days & 8 & 2 \\
\hline NA & 63 & 0 \\
\hline \multicolumn{3}{|c|}{$\begin{array}{c}\text { Table 6: Showing correlation between duration of illness } \\
\text { at the time of presentation and mortality }\end{array}$} \\
\hline
\end{tabular}

\begin{tabular}{|c|c|c|c|}
\hline $\begin{array}{c}\text { Sl. } \\
\text { No. }\end{array}$ & $\begin{array}{c}\text { Sp02 at } \\
\text { Presentation }\end{array}$ & $\begin{array}{c}\text { Total No. of } \\
\text { Cases }\end{array}$ & $\begin{array}{c}\text { Total } \\
\text { Mortalities }\end{array}$ \\
\hline 1 & $<=40$ & 16 & 14 \\
\hline 2 & $41-50 \%$ & 26 & 22 \\
\hline 3 & $51-60 \%$ & 36 & 25 \\
\hline 4 & $61-70 \%$ & 32 & 15 \\
\hline 5 & $71-80 \%$ & 45 & 25 \\
\hline 6 & $81-90$ & 50 & 25 \\
\hline 7 & $91-100$ & 17 & 18 \\
\hline 8 & NA & 63 & 4 \\
\hline \multicolumn{3}{|c|}{ Table 7: Showing SpO at time of } \\
presentation and mortality \\
\hline
\end{tabular}

\begin{tabular}{|c|c|c|c|}
\hline Sl. No. & $\begin{array}{c}\text { Male } \\
\text { (Admitted/ } \\
\text { Death) }\end{array}$ & $\begin{array}{c}\text { Female } \\
\text { Admitted( } \\
\text { Death) }\end{array}$ & $\begin{array}{c}\text { Total } \\
\text { (Admitted/ } \\
\text { Death) }\end{array}$ \\
\hline $\begin{array}{c}\text { Obesity(BMI>3 } \\
\text { 0) }\end{array}$ & $2(1)$ & $7(4)$ & $9(5)$ \\
\hline $\begin{array}{c}\text { Pregnancy/Pos } \\
\text { tpartum }\end{array}$ & - & $21(10)$ & $21(10)$ \\
\hline Hypertension & $10(5)$ & $18(7)$ & $28(12)$ \\
\hline Diabetes & $13(6)$ & $13(3)$ & $26(9)$ \\
\hline $\begin{array}{c}\text { Pulmonary } \\
\text { Tuberculosis }\end{array}$ & $3(2)$ & $4(2)$ & $7(4)$ \\
\hline $\begin{array}{c}\text { Bronchial } \\
\text { Asthma }\end{array}$ & $0(0)$ & $3(1)$ & $3(1)$ \\
\hline COPD & $4(0)$ & $2(0)$ & $6(0)$ \\
\hline $\begin{array}{c}\text { Coronary } \\
\text { Artery disease }\end{array}$ & $1(0)$ & $1(0)$ & $2(0)$ \\
\hline $\begin{array}{c}\text { Valvular Heart } \\
\text { disease }\end{array}$ & $1(0)$ & $3(1)$ & $4(1)$ \\
\hline Anemia & $21(2)$ & $62(7)$ & $83(9)$ \\
\hline Renal failure & $3(2)$ & $3(1)$ & $6(3)$ \\
\hline $\begin{array}{c}\text { Hypothyroidis } \\
\text { m }\end{array}$ & $0(0)$ & $2(0)$ & $2(0)$ \\
\hline CVA & $1(1)$ & $1(0)$ & $2(1)$ \\
\hline Table 9: Showing comorbid IIlnesses and Death \\
\hline \multicolumn{2}{|r|}{}
\end{tabular}

Out of 289 cases hospitalized with Category C ILI, 123 had no pre-existing medical problem. Of the other 187, most common preexisting conditions were obesity () followed by bronchial asthma (), COPD () cardiovascular diseases, etc. Of the total patients, 23 were pregnant and of the total pregnant patients with severe illness $89 \%$ died due to severe nonresponsive ARDS.

\begin{tabular}{|c|c|c|c|}
\hline Addiction & Male & Female & $\begin{array}{c}\text { Total } \\
\text { (Death) }\end{array}$ \\
\hline Smoking & 9 & 1 & $10(5)$ \\
\hline Alcohol & 7 & 1 & $8(5)$ \\
\hline Tobacco & 2 & 1 & $3(1)$ \\
\hline Total & $\mathbf{1 8}$ & $\mathbf{3}$ & $\mathbf{2 1 ( 1 1 )}$ \\
\hline $\begin{array}{c}\text { Table 10: Showing Addictions History } \\
\text { amongst the admitted patients }\end{array}$ \\
\hline
\end{tabular}

\begin{tabular}{|c|c|c|c|}
\hline & Male & Female & Total \\
\hline Gujarat & 2 & 1 & 3 \\
\hline Maharashtra & 3 & 1 & 4 \\
\hline Rajasthan & 2 & 3 & 5 \\
\hline Table 11: Showing Travel History of the patients \\
\hline
\end{tabular}

\begin{tabular}{|c|c|c|c|}
\hline $\mathrm{PaO}_{2} / \mathrm{FiO}_{2}$ & $\begin{array}{c}\text { Male } \\
\text { Admitted } \\
\text { (Death) }\end{array}$ & $\begin{array}{l}\text { Female } \\
\text { Admitted } \\
\text { (Death) }\end{array}$ & $\begin{array}{c}\text { Total } \\
\text { Admitted } \\
\text { (Death) }\end{array}$ \\
\hline$\leq 200$ & $13(11)$ & $12(11)$ & $25(22)$ \\
\hline$>200-300$ & $14(13)$ & $16(11)$ & $30(24)$ \\
\hline$>300-400$ & $7(2)$ & $6(3)$ & $13(5)$ \\
\hline$>400$ & $1(1)$ & $1(0)$ & $2(1)$ \\
\hline \multicolumn{4}{|c|}{$\begin{array}{c}\text { Table 8: Showing } \mathrm{PaO}_{2} / \mathrm{FiO}_{2} \text { at time } \\
\text { of presentation and mortality }\end{array}$} \\
\hline
\end{tabular}

DISCUSSION: In our observational study, the first case of H1N1 was hospitalized in our institute in January started cumulating from January 2015 and peak incidence occurred in February 2015.

The incidence in females was more than males. This finding is similar to other national and international studies on H1N1. 5 The incidence of category C illness as well as of laboratory proven $\mathrm{H} 1 \mathrm{~N} 1$ was highest in $15 \mathrm{yr}$. to $45 \mathrm{yr}$. age group. At the beginning of $\mathrm{H} 1 \mathrm{~N} 1$ pandemic it was postulated that it will affect extremes of age more, but our study too contributes to the available data. 
The incidence of severe Influenza-like illness requiring hospitalization in pediatric age group and in age more than 60 was very low, which is contrary to study findings of Hariharan Subramony et al., 6 who reported an approximate incidence of $29 \%$ in $0-15 \mathrm{yr}$. age group. The factor that can be contributing to high incidence in 15 to 40 age group could be higher chances of mobility making them more liable to exposure.

More cases were referred from peripheral hospital of nearby district than getting direct hospitalization. The rural urban distribution in our study was almost equal suggesting that both populations are affected by the illness.

The most common presenting complaint in our study was cough followed by fever, shortness of breath, hemoptysis and shock. Shortness of breath was the most ominous symptom, which was present in all patients who succumbed to H1N1 pneumonia in the present study.

The duration of illness varied between 1 to 21 days in our study, but most cases presented with 6 to 7 days' duration of illness. The mortality and duration of hospital stay increased with delayed presentation. In the present study, one of the key features that we found was the fact that patients presenting within 3 days of onset of symptoms had minimum mortality while patients presenting beyond 7 days had increased mortality and patients presenting beyond 12 days had maximum mortality.

Sp02 at presentation in our study came out as a promising tool for outcome prediction with Sp02 at room air 90 and above had less mortality while the mortality rates increased with falling Sp02 at presentation in Sp02 80 to 90 and in Sp02 70 to 80 while it was highest on Sp02, less than 70 at presentation. Thus in our opinion SPO2 is one of the simplest bedside prognostic tool appearing very promising in management of H1N1. We could not find any data correlating Sp02 with outcome prediction in H1N1; this needs further evaluation and may prove to be a simple bedside test for triaging cases with suspected H1N1.

As far as ABG values were concerned, in our study we found that lower $\mathrm{PaO} 2 / \mathrm{FiO} 2$ values were associated with increase in mortality. Like previously available studies, ${ }^{5,6}$ the mortality rates increased with falling $\mathrm{PaO} 2 / \mathrm{FiO2}$. In our study 192 patients presented with Pa02/Fi02, less than 300 which is defining criteria for acute lung injury.

All comorbidities were evaluated individually, but correlation with anemia was most common in our study to the extent that in $100 \%$ female patients with swine flu, there was correlation with various grades of anemia (Mild, moderate and severe). Correlation of anemia with increased incidence of Swine flu is an important finding in the present study and needs further evaluation for confirming definite association.

H1N1 virus is now present in our community as common influenza-like illness causing agent. Previous years experiences suggested that the disease caused by this virus is relatively mild, but the sudden increase in incidence during 2014-2015 causing thousands of death over India and other parts of world puts it right on the radar again. Our observational study shows that picking the disease early is the key to effective management. Pregnancy, anemia, obesity and pre-existing respiratory illnesses are associated with increased mortality and need earlier intervention.

The guidelines of people at risk needs further evaluation with more studies to check the significance of obesity, and anemia whose presence increased morbidity and mortality in our study.

\section{REFERENCES:}

1. The 2009 H1N1 Pandemic: Summary Highlights, April 2009-April 2010, CDC, Atlanta available at http://www.cdc.gov/h1n1flu/cdcresponse.htm accessed on 25 June 2015.

2. Statement by WHO Director-General, Dr Margaret Chan 25 April 2009 available at

http://www.who.int/mediacentre/news/statements/200 9/h1n1_20090425/en/index.html accessed on 25 June 2015.

3. "Origins and evolutionary genomics of the 2009 swineorigin H1N1 influenza A epidemic: Article". Nature. Retrieved 2011-08-17.

4. Margaret Chan's statement - H1n1 pandemic is over Available at:

http://www.who.int/mediacentre/news/statements/201 0/h1n1_vpc_20100810/en/index.html accessed on 25 June 2015.

5. Demographic correlates of Swine Flu cases attending a tertiary care hospital in Rajasthan, Sharma C. P et al., IJPSM Vol. 43. No. 22012 ISSN-0301-1216.

6. Epidemiology of Pandemic H1N1 Hospitalized Cases Accessed by authors on 30-06-2015 in www.annals.edu.sg/pdf/39volno4apr2010/v39n4p283.p $\mathrm{df}$ 